\title{
STAT3 Deficiency
}

National Cancer Institute

\section{Source}

National Cancer Institute. STAT3 Deficiency. NCI Thesaurus. Code C126342.

A condition of decreased or absent presence or activity of signal transducer and activator of transcription 3 protein. Deficiency of this protein is associated with hyper-IgE syndrome. 